\title{
Edukasi Pentingnya Bakteri Asam Laktat (BAL) Terhadap Kesehatan Saluran Cerna Bayi
}

\author{
Suci Rahmani Nurita ${ }^{1}$, Tuhu Perwitasari ${ }^{2}$ \\ ${ }^{1,2}$ Program Studi Sarjana Kebidanan \& Pendidikan Profesi Bidan, STIKes Baiturrahim Jambi \\ Email: srnurita@gmail.com
}

Submitted : 24/10/21

Accepted: 02/11/2021

Published: 17/11/2021

\begin{abstract}
Infant Mortality Rate is one indicator that determines health status. Every year there are 3 million infant deaths in the world, $80 \%$ of which occur in the first 6 days of life, with pneumonia and diarrhea still being the main causes of death. Based on Nurita's research (2019) on postpartum mothers and newborns, which aims to determine the relationship between the frequency of giving colostrum and birth mode with the number of Lactic Acid Bacteria (LAB) colonies in the neonatal gastrointestinal tract. The results of the study found that the number of LAB colonies in babies born vaginally and C-Section was not much different, but the number of LAB colonies would increase in number if breast milk was often given. The education carried out targets an increase in the knowledge of educational participants with the outputs in the form of informative leaflets, educational video, educational X-Banners, activity reports and journal publications. Community service activities begin with licensing arrangements, time contracts, preparation of educational tools and materials, visits to Independent Midwives Practice (PMB, explanations of educational materials, discussions and questions-answers, showing educational videos, and handing over Educational X-Banners. It can be concluded that educational participants are still unfamiliar with lactic acid bacteria $(L A B)$ and their role in the health of the baby's gastrointestinal tract, so further education is needed.
\end{abstract}

Keywords: baby's gastrointestinal tract, lactic acid bacteria, mother's milk (ASI), probiotics

\begin{abstract}
Abstrak
Angka Kematian Bayi merupakan salah satu indikator yang menentukan derajat kesehatan. Setiap tahun terjadi 3 juta kematian bayi di dunia yang dilaporkan $80 \%$ terjadi pada periode 6 hari pertama kehidupan dengan pneumonia dan diare yang masih menjadi penyebab utama kematian. Berdasarkan penelitian Nurita (2019) pada ibu postpartum dan bayi baru lahir yang bertujuan untuk mengetahui hubungan kekerapan pemberian kolostrum dan cara lahir dengan jumlah koloni Bakteri Asam Laktat (BAL) di saluran cerna neonatus. Hasil penelitian menemukan jumlah koloni BAL pada bayi yang lahir pervaginam ataupun perabdominal tidak jauh berbeda namun jumlah koloni BAL akan semakin meningkat jumlahnya jika kerap diberikan Air Susu Ibu (ASI). Edukasi yang dilakukan menargetkan adanya peningkatan pengetahuan peserta edukasi dengan luaran berupa leaflet informatif video edukasi, X-Banner edukasi, laporan hasil kegiatan dan publikasi jurnal. Kegiatan pengabdian kepada masyarakat diawali dengan pengurusan perijinan, kontrak waktu, persiapan alat dan bahan edukasi, kunjungan ke PMB, penjelasan materi edukasi, diskusi dan tanya jawab, penayangan video edukasi, serta penyerahan X-Banner Edukasi.. Dapat disimpulkan peserta edukasi masih awam dengan bakteri asam laktat dan peranannya terhadap kesehatan saluran cerna bayi sehingga masih diperlukan edukasi lanjutan.
\end{abstract}

Kata Kunci: Air Susu Ibu (ASI), bakteri asam laktat, probiotik, saluran cerna bayi

\section{PENDAHULUAN}

Angka Kematian Bayi (AKB) merupakan salah satu indikator yang menentukan derajat kesehatan. Setiap tahun terjadi 3 juta kematian bayi di dunia yang dilaporkan $80 \%$ terjadi pada periode 6 hari pertama kehidupan dengan pneumonia dan diare yang masih menjadi penyebab utama kematian (Kementerian Kesehatan RI, 2020). United Nation Children's Fund 
(UNICEF) menyatakan sebanyak 30.000 kematian bayi di Indonesia dapat dicegah melalui pemberian ASI terutama pemberian kolostrum. Hajeebhoy et al. juga menemukan bayi yang mendapatkan kolostrum mendapat protektif lebih besar dari ancaman infeksi diare dan ISPA daripada bayi yang tidak mendapat kolostrum (Edmond et al.2006).

Kolostrum adalah makanan ideal bagi bayi baru lahir yang banyak mengandung zat antibodi dalam konsentrasi tinggi serta faktor-faktor pertumbuhan dan vitamin yang larut dalam lemak. Beberapa penelitian menunjukkan bahwa ASI terutama kolostrum merupakan sumber Bakteri Asam Laktat (BAL) terbesar bagi bayi. Beberapa genus bakteri yang termasuk dalam kelompok BAL diantaranya Lactobacillus, Streptococcus dan Bifidobacteria yang dominan terdapat pada feses bayi yang mendapat ASI (Mcguire \& Mcguire, 2015; Lee et al. 2015).

Bakteri Asam Laktat (BAL) merupakan mikrobiota saluran cerna yang berperan penting terhadap kesehatan manusia diantaranya merangsang daya tahan tubuh baik seluler maupun humoral, meningkatkan kemampuan penyerapan beberapa nutrisi, menjaga $\mathrm{PH}$ usus sehingga dapat melindungi dari mikroorganisme patogen, menjaga gangguan dalam penyerapan air, melancarkan pencernaan dengan memproduksi beberapa enzim pencernaan dan vitamin, meningkatkan pergerakan usus sehingga membebaskan konstipasi dan menghasilkan subtansi antibakteri yang mampu membunuh mikroorganisme patogen penyebab penyakit infeksi (Syukur \& Purwati, 2013).

PMB Yustati Ambarita, S.Tr.Keb terletak di wilayah Kelurahan Pijoan Kecamatan Jambi Luar Kota Kabupaten Muaro Jambi tepatnya setelah SMAN 1 Muaro Jambi.

Survey awal yang dilakukan pada masyarakat di wilayah kerja PMB Yustati Ambarita, S.Tr.Keb khususnya ibu yang baru melahirkan (postpartum) dan ibu yang menyusui masih memiliki pengetahuan yang rendah tentang (1) ASI yang banyak mengandung Bakteri Asam Laktat (BAL) dan manfaatnya bagi kesehatan saluran cerna bayi (2) belum adanya edukasi mengenai pentingnya BAL bagi kesehatan saluran cerna bayi.

Berdasarkan permasalahan mitra tersebut, dapat diketahui bahwa masyarakat di lingkungan PMB Yustati Ambarita, S.Tr.Keb memiliki 2 masalah. Tim Pengabdian masyarakat akan fokus memberikan pengabdian dalam bentuk edukasi kesehatan mengenai pentingnya Bakteri Asam Laktat (BAL) terhadap kesehatan saluran cerna bayi.

Tujuan dari kegiatan pengabdian kepada masyarakat ini yaitu menciptakan leaflet, video edukasi dan X-Banner edukasi yang informatif dalam menyampaikan pesan dan memberikan edukasi kesehatan tentang pentingnya BAL bagi kesehatan saluran cerna bayi dengan harapan dapat meningkatkan pengetahuan ibu.

\section{TARGET DAN LUARAN}

Kegiatan pengabdian ini memiliki target yaitu :

a. Adanya respons positif dari peserta edukasi selama proses edukasi berlangsung

b. Adanya peningkatan pengetahuan peserta edukasi

Luaran dari kegiatan pengabdian ini yaitu :

a. Leaflet yang informatif (cetak \& softfile)

b. Video Edukasi (bisa ditayangkan dan diakses kapanpun lewat kanal Youtube)

c. Pemasangan X-Banner Edukasi di PMB

d. Laporan kegiatan

e. Publikasi artikel dalam jurnal ilmiah nasional berISSN 


\section{METODE PELAKSANAAN}

Kegiatan ini dilaksanakan selama 6 bulan dari bulan Maret 2021 sampai dengan Agustus 2021 di PMB Yustati Ambarita, STr.Keb

Sasaran dalam kegiatan pengabdian ini adalah Bidan-bidan dan ibu postpartum yang memiliki bayi usia 0-1 tahun di wilayah PMB Yustati Ambarita, S.Tr.Keb Kelurahan Pijoan Kecamatan Jaluko Muaro Jambi. Adapun kontribusi peserta dalam pengabdian masyarakat ini adalah menjadi peserta kegiatan pengabdian, dan mengaplikasikan hasil edukasi yang telah di laksanakan

Tahapan pelaksanaan kegiatan pengabdian kepada masyarakat ini adalah sebagai berikut:

1. Kegiatan awal/persiapan

a. Mengkaji dan menganalisis data

b. Mengidentifikasi masalah

c. Menyusun usulan kegiatan pengabdian kepada masyarakat

d. Menyusun bahan materi untuk disampaikan kepada sasaran

e. Mengurus izin lokasi pengabdian kepada masyarakat

2. Pelaksanaan kegiatan

a. Perkenalan antara pemberi materi dengan sasaran.

b. Penjelasan kegiatan dan tujuan dari kegiatan yang akan dilakukan

c. Melaksanakan pemberian edukasi dengan menggunakan penayangan video, pemberian leaflet (cetak dan soft file) dan pemasangan X-Banner edukasi di PMB.

d. Memberikan kesempatan kepada peserta untuk bertanya tentang materi yang diberikan dan memberi penjelasan dari pertanyaan yang diajukan.

e. Penutupan.

3. Penyusunan dan penyerahan laporan

a. Merumuskan hasil pengabdian masyarakat b. Mengumpulkan dokumentasi dan lampiran yang mendukung (daftar hadir, foto-foto dan surat-surat)

c. Menyerahkan laporan kepada tim PPPM.

\section{HASIL DAN PEMBAHASAN \\ Hasil}

Pengabdian kepada masyarakat dimulai dari mengkaji dan menganalisis data yang didapatkan dari PMB Yustati Ambarita, S.Tr.Keb dilanjutkan dengan mengidentifikasi masalah untuk menentukan kegiatan yang akan diberikan. Kemudian menyusun bahan dan materi edukasi untuk disampaikan kepada sasaran. Selanjutnya mengurus izin lokasi pengabdian masyarakat kepada pimpinan PMB tersebut. Pelaksanaan kegiatan bertempat di wilayah PMB Yustati Ambarita, S.Tr.Keb Kelurahan Pijoan Kecamatan Jaluko Muaro Jambi dengan kegiatan edukasi, penyebaran leaflet dan pemasangan X-Banner Edukasi. Setelah itu dilakukan penyusunan laporan kegiatan dan publikasi jurnal ilmiah.

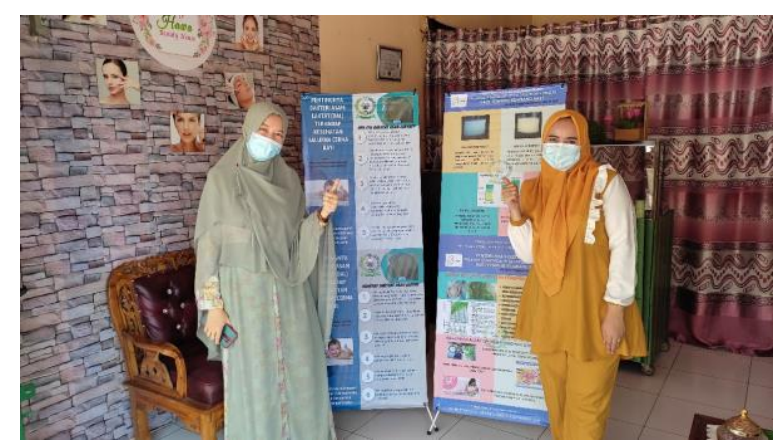

Gambar 1. Pemasangan X-Banner Edukasi

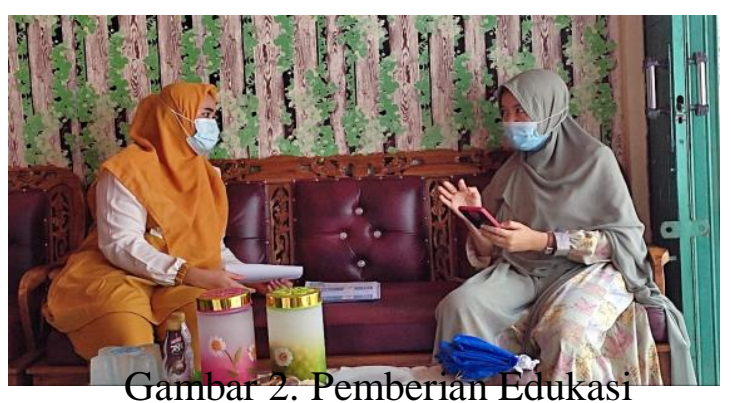

PENTINGNYA BAKTERI ASAM LAKTAT (BAL) TERHADAP KESEHATAN SALURAN CERNA BAYI 
cerna bayi yang difasilitasi oleh kolostrum (Kusumo, 2012; IDAI, 2008).

Perkembangan terkini menunjukkan adanya beragam komponen bioaktif di dalam ASI terutama kolostrum yang memfasilitasi pertumbuhan, modulasi dan pematangan sistem kekebalan tubuh bayi. Beberapa diantaranya adalah Laktoferin, Human Milk Oligosaccharides (HMO) dan Mikrobiota (Bakteri Asam Laktat) (Permaesih et al. 2009).

Kolonisasi

mikrobiota menguntungkan seperti kelompok BAL merupakan mekanisme pertahanan utama untuk mencegah translokasi bakteri tertentu. BAL akan mencegah berlipatgandanya bakteri yang berpotensi patogen. Pencegahan ini disebut resistensi kolonisasi. Hubungan antara mikrobiota usus dan inangnya (manusia) sangatlah spesifik sehingga perubahan keseimbangan mikrobiota dapat menimbulkan penyakit. Keseimbangan mikrobiota dapat tercapai apabila perbandingan antara mikrobiota menguntungkan terhadap mikrobiota merugikan adalah sebesar 85:15 atau 80:20 (Syukur \& Purwati, 2013).

\section{KESIMPULAN DAN SARAN \\ 1. Kesimpulan}

Berdasarkan kegiatan pengabdian yang telah dilaksanakan di PMB Yustati Ambarita, S.Tr.Keb, maka dapat disimpulkan bahwa:

a. Terjadinya perubahan pengetahuan yang baik pada sasaran

b. Sasaran mampu menjawab dengan benar pertanyaan terkait pentingnya bakteri asam laktat bagi kesehatan saluran cerna bayi

\section{Saran}

a. Bagi Sasaran

Diharapkan dapat mengimplementasikan pengetahuan yang didapat agar dapat mempraktekkan pemberian kolostrum selama 4 hari pertama kelahiran dan 
ASI secara eksklusif untuk membentuk kekebalan tubuh bayi

b. Bagi PMB Yustati Ambarita

Diharapkan dapat mengadakan edukasi lanjutan dan kontinu terkait pentingnya bakteri asam laktat pada ASI yang berpengaruh terhadap proses kekebalan tubuh bayi.

c. Bagi Sekolah Tinggi Ilmu Kesehatan Baiturrahim Jambi

Diharapkan memotivasi dosen untuk melakukan kegiatan tridharma perguruan tinggi khususnya untuk memberikan penyuluhan yang dapat meningkatkan pengetahuan ibu mengenai pentingnya bakteri asam laktat pada ASI dan pengaruhnya terhadap kekebalan tubuh bayi

\section{UCAPAN TERIMAKASIH}

Terimakasih kepada segenap pimpinan dan pegawai PMB Yustati Ambarita, STr.Keb, Ketua STIKes Baiturrahim Jambi (STIKBA) dan Ketua P3M STIKBA yang telah memfasilitasi dan memberi dukungan bagi kegiatan pengabdian masyarakat ini baik secara materil, moril dan administratif. Terimakasih kepada Ibu Bayi/Balita dan Mahasiswa Prodi DIII Kebidanan STIKBA yang terlibat aktif dan membantu pelaksanaan sehingga kegiatan pengabdian masyarakat ini bisa berjalan lancar sesuai harapan.

\section{DAFTAR PUSTAKA}

Edmond, K.M., Zandoch, C., Quigley, M.A., Amenga-Etego, S., OwusuAgyei, S., \& Kirkwood, B.R. (2006). Delayed Breastfeeding Initiation Increases Risk of Neonatal Mortality. Pediatrics Official Journal of the American Academy of Pediatrics. Vol.117(3). pp.380-386

Ikatan Dokter Anak Indonesia. (2008). Bedah ASI. Jakarta: Balai Penerbit FK UI.

Kementerian Kesehatan Republik
Indonesia. (2020). Profil Kesehatan Indonesia Tahun 2019. Jakarta: Kementerian Kesehatan Republik Indonesia.

Kusumo, P. D. (2012). Kolonisasi Mikrobiota Normal dan Pengaruhnya Pada Perkembangan Sistem Imunitas Neonatal. Jurnal Kedokteran FKUK. Vol. 29(320). pp. 55-63.

Lee SA, Lim JY, Kim BS, Cho SJ, Kim NY, Kim OB et al. (2015). Comparison of the Gut Microbiota Profile in Breast-fed and Formula-fed Korean Infants Using Pyrosequencing. Nutrition Research and Practice. pp. 242-248.

Mcguire, M. K., \& Mcguire, M. A.. (2015). Human Milk : Mother Nature Prototypical. American Society for Nutrition. Vol.6. pp.112-113.

Nurita, S. R., Mayetti, M., \& Masrul, M. (2019). Hubungan Kekerapan Pemberian Kolostrum dan Cara Lahir dengan Jumlah Koloni Bakteri Asam Laktat di Saluran Cerna Neonatus. Jurnal Ilmiah Universitas Batanghari Jambi, 19(1), 104-109.

Penders, J., Thijs, C., Vink, C., Stelma, F.F., Snijders, B., Kummeling, I., et al. (2005). Factors Influencing the Composition of the Intestinal Microbiota in Early Infancy. American Academy of Pediatrics. Vol 118(2). pp. 511-521.

Permaesih, D., Hardinsyah, Setiawan, B., \& Tanumihardjo, S.A. (2009). Kadar sIgA dan Lactoferrin ASI. Gizi Indon. Vol. 32(1). pp. 1-9.

Rahmagiarti, C., Prayitno, L., Oswari, H., \& Abinawanto. (2013). Perkembangan Kolonisasi Bifidobacterium Pada Usus Bayi. FMIPA UI. pp. 1-6

Syukur, S \& Purwati, E. (2013). Bioteknologi Probiotik Untuk Kesehatan Masyarakat. Yogyakarta: CV. Andi Offset 